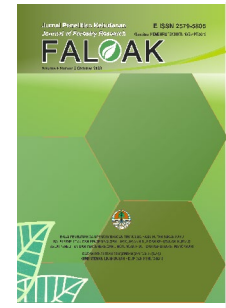

Jurnal Penelitian Kehutanan Faloak (2021) 5(2), 90-102

JURNAL PENELITIAN KEHUTANAN FALOAK

Akreditasi KEMENRISTEKDIKTI: 10/E/KPT/2019
tp://ejournal.forda-mof.org/ejournal-litbang/index.php/JPKF

e-ISSN 25795805

\title{
KARAKTERISTIK DAN POTENSI PEMBERDAYAAN MASYARAKAT BUKIT DATUK DALAM PENGELOLAAN HUTAN PATRA SEROJA \\ PT. PERTAMINA RU II DUMAI PROVINSI RIAU \\ (Characteristics and Empowerment Potential of Bukit Datuk Community in Patra Seroja Forest Management PT. Pertamina RU II Dumai, Riau Province)
}

\author{
Denni Susanto ${ }^{1 *}$, Heni Puji Astuti ${ }^{2}$, Muhammad Ali Imron $^{2}$ dan Arizal ${ }^{3}$ \\ ${ }^{1}$ Prodi Pengelolaan Hutan, Sekolah Vokasi, Universitas Gadjah Mada, Yogyakarta 55281 \\ ${ }^{2}$ Fakultas Kehutanan, Universitas Gadjah Mada, Yogyakarta 55281 \\ ${ }^{3}$ PT. Pertamina (Persero) Refinery Unit II Dumai, Jl. Putri Tujuh - Dumai
}

\begin{abstract}
This study aimed to determine the characteristics and empowerment potential program for the Bukit Datuk community in maintaining biodiversity in the Patra Seroja forest PT. Pertamina RU II Dumai. The study used qualitative approach through literature study, field observations, and interviews. Interviews were conducted with 10 key informants and 30 respondents who were determined using purposive sampling. The results showed that the majority of the Bukit Datuk community had a high education level (32.03\%) and the type of livelihood was self-employed (12.67\%) as the potential supporter of empowerment. Empowerment programs for the Bukit Datuk community included strengthening community groups, the formation of community groups that have interaction with forest area, developing natural resources on private/village land, participatory mapping and conflict resolution on oil palm estate problems, and enhancing public awareness and developing supporting infrastructure for waste management around the Patra Seroja Forest.
\end{abstract}

Keywords: community, Bukit Datuk, empowerment, Patra Seroja Forest, PT. Pertamina

\begin{abstract}
ABSTRAK
Penelitian ini bertujuan untuk mengetahui karakteristik dan potensi pemberdayaan masyarakat Bukit Datuk dalam menjaga keanekaragaman hayati di Hutan Patra Seroja PT. Pertamina RU II Dumai. Metode penelitian yang digunakan adalah pendekatan kualitatif melalui studi pustaka, observasi lapangan, dan wawancara. Wawancara dilakukan terhadap 10 informan kunci dan 30 masyarakat yang ditentukan dengan menggunakan purposive sampling. Analisis data menggunakan analisis deskriptif kualitatif. Hasil penelitian menunjukkan bahwa mayoritas masyarakat Bukit Datuk memiliki tingkat pendidikan SLTA $(32,03 \%)$ dan jenis pekerjaan wiraswasta $(12,67 \%)$ sebagai potensi pendukung pemberdayaan. Program pemberdayaan masyarakat Bukit Datuk di antaranya adalah pembentukan kelompok masyarakat yang memiliki interaksi terhadap kawasan hutan, penguatan kelompok masyarakat, pengembangan sumber daya alam di lahan milik/desa, pemetaan partisipatif serta penerapan solusi jalan tengah permasalahan lahan sawit dan peningkatan kesadaran masyarakat serta pengembangan sarana prasarana pendukung pengelolaan sampah sekitar Hutan Patra Seroja.
\end{abstract}

Kata kunci: masyarakat, Bukit Datuk, pemberdayaan, Hutan Patra Seroja, PT. Pertamina

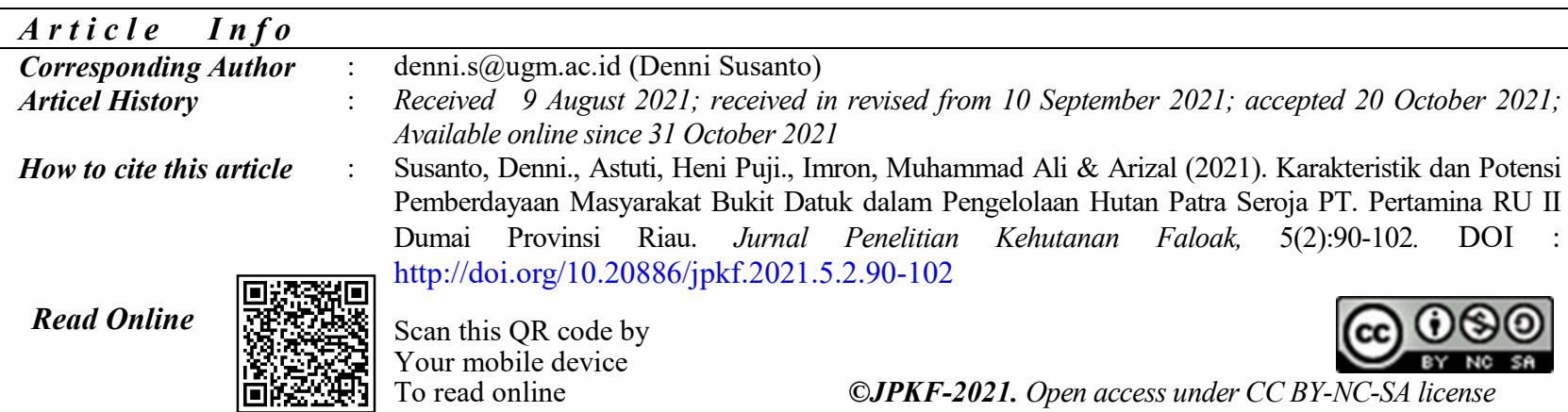




\section{PENDAHULUAN}

Masyarakat sekitar hutan dan kawasan hutan merupakan dua hal yang tidak dapat dipisahkan. Masyarakat melakukan interaksi dengan hutan untuk memenuhi kebutuhannya (Susanto et al., 2020). Masyarakat sekitar hutan merupakan masyarakat yang hidup di sekitar hutan dan menggantungkan hidupnya dari sumber daya yang ada di dalam hutan (Neil, Golar, \& Hamzari 2016). Interaksi masyarakat dengan kawasan hutan akan bernilai positif apabila pandangan masyarakat terhadap hutan baik, begitu juga sebaliknya (Hangi, Rizalinda, \& Irwan, 2014). Perberdayaan merupakan salah satu upaya yang dapat dilakukan untuk mengurangi dampak negatif dari interaksi masyarakat dan hutan.

Kegiatan pemberdayaan masyarakat merupakan salah satu upaya dalam menjaga kelestarian hutan serta meningkatkan kesejahteraan masyarakat. Pemberdayaan masyarakat sekitar hutan dapat dilakukan dengan merancang program pemberdayaan dan atau membentuk kelompok pemberdayaan masyarakat (Choiria, 2015). Salah satu indikator untuk menilai keberhasilan pemberdayaan masyarakat adalah tingkat partisipasi dari masyarakat itu sendiri dalam berinteraksi dengan kawasan hutan (Sugiartono \& Dhamayanthi, 2016).

Ecopark atau Hutan Patra Seroja adalah kawasan hutan yang terdapat di kota Dumai, Provinsi Riau. Kawasan hutan ini merupakan kawasan hutan yang berfungsi menjaga keanekaragaman hayati dan menjadi salah satu kawasan hutan yang dikelola PT. Pertamina RU II Dumai. Hutan Patra Seroja tergolong hutan yang masih baik karena masih ditemukan beberapa spesies burung dengan indeks keanekaragaman 2,63 (sedang) (Heriyanto et al., 2019). Namun karena lokasinya berbatasan dengan Kelurahan Bukit Datuk, kawasan hutan
Patra Seroja memiliki tekanan sosial tinggi. Interaksi masyarakat Bukit Datuk dengan Hutan Patra Seroja sudah berlangsung lama, salah satunya aktivitas pemanfaatan sumber daya alam yang ada di dalam hutan oleh masyarakat.

Hutan Patra Seroja mempunyai fungsi penting baik secara ekologi yaitu untuk menjaga keanekaragaman hayati, maupun secara sosial yaitu untuk menunjang keberlangsungan hidup masyarakat sekitar (Gerihano et al., 2016). Oleh karena itu, dalam pengelolaannya PT. Pertamina RU II Dumai juga harus memperhatikan kondisi masyarakat sekitar karena Kelurahan Bukit Datuk termasuk dalam wilayah kerja PT. Pertamina RU II Dumai (Hesti et al., 2021). Salah satu upaya untuk menjaga kelestarian Hutan Patra Seroja dan meningkatkan kesejahteraan masyarakat Bukit Datuk adalah dengan program pemberdayaan bagi masyarakat sekitar. Pemberdayaan yang dilakukan akan meningkatkan peran serta dan kemandirian, sehingga masyarakat memiliki ruang untuk mengembangkan potensi dan sumber daya yang dimiliki (Reski et al., 2017).

Pemberdayaan masyarakat di Kelurahan Bukit Datuk pada saat ini belum banyak dilakukan dan juga belum berhasil. Berdasarkan laporan social mapping PT. Pertamina RU II Dumai (2018), pemberdayaan terakhir yang dilakukan yaitu peningkatan kapasitas masyarakat dalam pengembangan pertanian holtikultura tahun 2017 dan pengembangan instalasi air tahun 2018, namun upaya tersebut dinilai masih belum optimal. Masyarakat masih memanfaatkan lahan PT. Pertamina di sekitar kawasan Hutan Patra Seroja untuk kepentingan ekonomi. Ekspansi lahan tersebut bila terus dibiarkan akan menjadi ancaman bagi kelestarian Hutan Patra Seroja karena Kelurahan Bukit Datuk merupakan pintu utama untuk masuk ke Hutan Patra Seroja. Oleh karena itu, penelitian ini bertujuan untuk mengetahui 
karakteristik masyarakat Bukit Datuk dan potensi program pemberdayaannya sebagai upaya menjaga keanekaragaman hayati di Hutan Patra Seroja PT. Pertamina RU II Dumai.

\section{METODE PENELITIAN}

\section{A. Lokasi dan Waktu Penelitian}

Penelitian ini dilakukan di Kelurahan
Kabupaten Dumai. Kelurahan Bukit Datuk dipilih karena lokasinya yang berbatasan langsung dengan Hutan Patra Seroja dan merupakan pintu masuk menuju Hutan Patra Seroja (Gambar 1). Pengambilan data dilakukan pada bulan Juli 2021, sedangkan analisis data dilaksanakan pada bulan Juli sampai dengan Agustus 2021.

Bukit Datuk, Kecamatan Dumai Selatan,

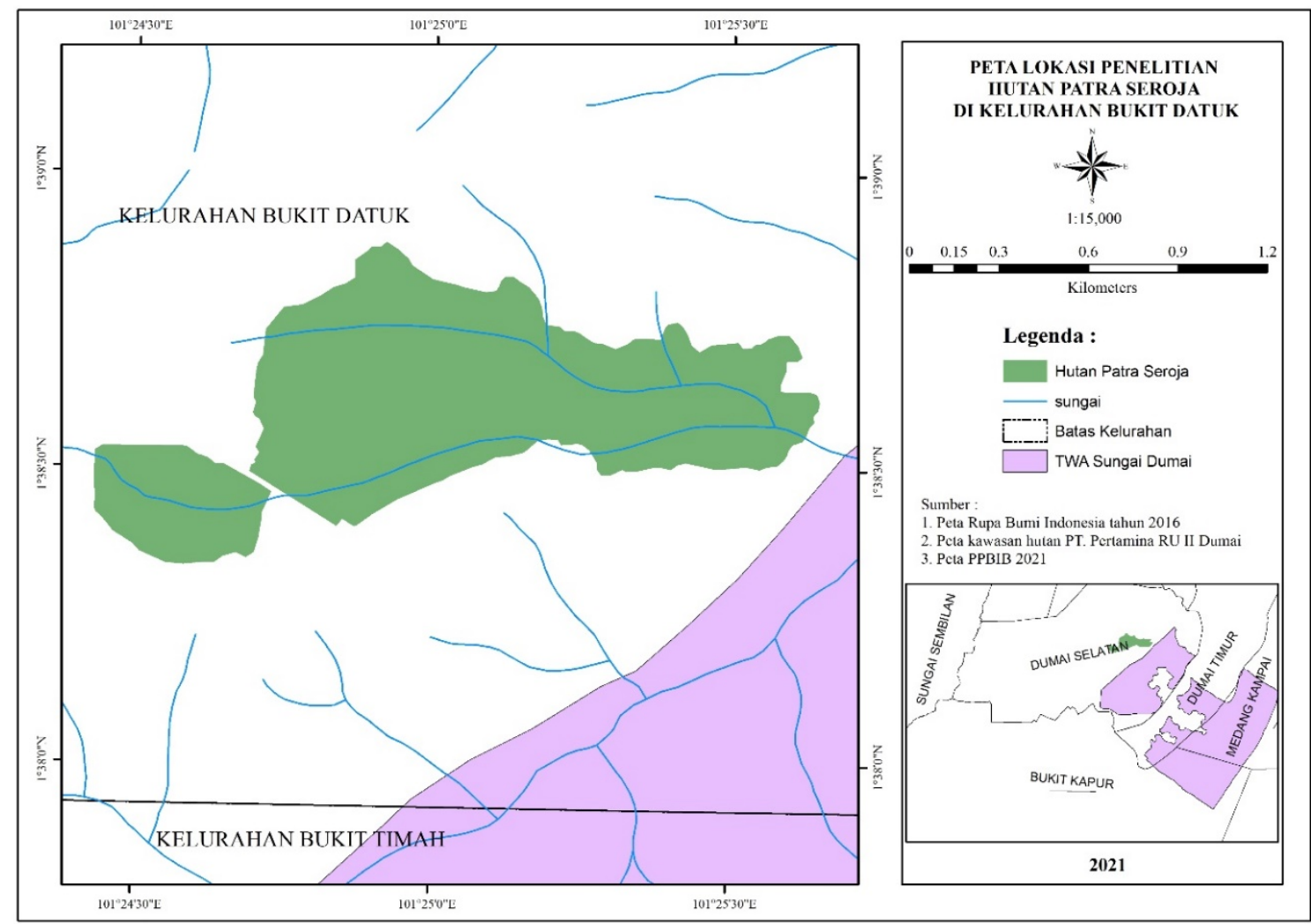

Gambar 1. Peta lokasi penelitian Hutan Patra Seroja di Kelurahan Bukit Datuk Kecamatan Dumai Selatan

Figure 1. Map of research location Patra Seroja Forest in Bukit Datuk Village, Dumai Selatan Sub Distict

\section{B. Rancangan penelitian dan analisis data}

Penelitian ini dilakukan dengan tiga pendekatan yaitu kajian pustaka, observasi lapangan, dan wawancara. Beberapa topik pertanyaan yang digunakan untuk mengetahui karakteristik masyarakat dan program pemberdayaan yang telah dilaksanakan adalah terkait dengan kondisi sosial ekonomi masyarakat, program pemberdayaan yang sudah berjalan, dan interaksi masyarakat dengan kawasan Hutan Patra Seroja. Wawancara dilakukan terhadap 10 informan kunci dan 30 masyarakat yang beraktivitas di kawasan Hutan Patra Seroja yang dipilih menggunakan metode 
purposive sampling. Informan kunci adalah tokoh atau masyarakat yang mengetahui sejarah desa dan Hutan Patra Seroja (Sugiyono, 2020). Masyarakat yang diwawancarai memiliki kriteria masyarakat Kelurahan Bukit Datuk yang pernah atau masih melakukan interaksi langsung di kawasan Hutan Patra Seroja, berusia minimal 18 tahun, dan dalam 1 kartu keluarga tidak boleh lebih dari satu orang yang diwawancara. Data yang diperoleh selanjutnya dianalisis secara deskriptif kualitatif. Analisis ini dilakukan dengan mereduksi data hasil wawancara yang sudah dilakukan menjadi bentuk informasi yang disajikan dalam hasil penelitian (Susanto et al., 2021).

\section{HASIL DAN PEMBAHASAN}

\section{A. Karakteristik Masyarakat Kelurahan Bukit Datuk}

Kelurahan Bukit Datuk merupakan salah satu dari lima kelurahan yang terdapat di Kecamatan Dumai Selatan. Pada awalnya, Bukit Datuk merupakan dusun kecil yang masuk dalam wilayah kepenghuluan Pangkalan Sesai, Kecamatan Dumai Barat, Kabupaten Bengkalis.
Sehubungan dengan perubahan status pemerintahan dan berdasarkan Peraturan Daerah Nomor 08 Tahun 2009, Kelurahan Bukit Datuk termasuk dalam salah satu wilayah pemekaran yang diresmikan masuk ke dalam wilayah Kecamatan Dumai Selatan. Berdasarkan jumlah penduduknya, Kelurahan Bukit Datuk mempunyai penduduk terbanyak di Kecamatan Dumai Selatan (BPS, 2019). Pada tahun 2019, jumlah penduduk di Kelurahan Bukit Datuk sebesar 16.127 jiwa dengan jumlah laki-laki 8.241 jiwa dan perempuan 7.886 jiwa. Kepadatan penduduk Kelurahan Bukit Datuk rata-rata sebesar $598 \mathrm{jiwa} / \mathrm{km}^{2}$.

Berdasarkan tingkat pendidikan, masyarakat Kelurahan Bukit Datuk merupakan masyarakat yang sadar akan pendidikan. Persentase terbesar jenjang pendidikan masyarakat di Bukit Datuk adalah SLTA yaitu $32,03 \%$, kemudian diikuti dengan tamatan SD 7,63\% dan Strata 1 yakni 7,51\%. Akan tetapi, permasalahan putus sekolah pada jenjang SD juga masih dijumpai yakni sebesar 1.287 orang atau 23,71\% (Tabel 1).

Tabel 1. Tingkat pendidikan masyarakat di Kelurahan Bukit Datuk

Table 1. Community education level in Bukit Datuk Village

\begin{tabular}{|c|c|c|}
\hline $\begin{array}{c}\text { Tingkat Pendidikan } \\
\text { (Education Level) }\end{array}$ & $\begin{array}{l}\text { Jumlah } \\
\text { (Total) }\end{array}$ & $\begin{array}{l}\text { Persentase } \\
\text { (Percentage) }\end{array}$ \\
\hline Belum sekolah & 2.933 & 23,71 \\
\hline Tidak Tamat SD & 1.287 & 10,41 \\
\hline Tamat SD & 944 & 7,63 \\
\hline SLTP & 1.398 & 11,3 \\
\hline SLTA & 3.961 & 32,03 \\
\hline Diploma I & 211 & 1,71 \\
\hline Diploma II & 646 & 5,22 \\
\hline Strata I & 929 & 7,51 \\
\hline Strata II & 59 & 0,48 \\
\hline Jumlah & 12.368 & 100 \\
\hline
\end{tabular}


Tingkat pendidikan akan memengaruhi kualitas dan pekerjaan yang didapatkan, serta dapat berpotensi mengurangi pengangguran. Dalam konteks pengelolaan keanekaragaman hayati, tingkat pendidikan menjadi faktor yang penting. Semakin bagus tingkat pendidikan di suatu desa akan memengaruhi cara pandang seseorang terhadap pentingnya keanekaragaman hayati (Yuwono, 2006).

Mata pencaharian masyarakat Bukit
Datuk mayoritas adalah wiraswasta dan karyawan BUMN dengan persentase berturutturut sebesar 12,67\% dan 12,26\% (Tabel 2). Banyaknya jumlah karyawan BUMN yang berada di Kelurahan Bukit Datuk dikarenakan wilayah kelurahan ini yang berada di komplek perumahan milik PT. Pertamina (Persero) RU II Dumai. Beberapa mata pencaharian lainnya adalah PNS, buruh harian lepas, pedagang, guru, sopir, karyawan honorer, dan petani.

Tabel 2. Jenis pekerjaan masyarakat di Kelurahan Bukit Datuk Table 2. Types of community livelihood in Bukit Datuk Village

\begin{tabular}{|c|c|c|}
\hline $\begin{array}{c}\text { Mata Pencaharian } \\
\text { (Livelihood) }\end{array}$ & $\begin{array}{c}\text { Jumlah } \\
\text { (Total) }\end{array}$ & $\begin{array}{c}\text { Persentase } \\
\text { (Percentage) }\end{array}$ \\
\hline Wiraswasta & 802 & 12,67 \\
\hline Karyawan BUMN & 776 & 12,26 \\
\hline PNS & 455 & 7,19 \\
\hline Buruh harian lepas & 396 & 6,25 \\
\hline Pedagang & 59 & 0,93 \\
\hline Guru & 138 & 2,18 \\
\hline Sopir & 37 & 0,58 \\
\hline Karyawan honorer & 82 & 1,3 \\
\hline Petani atau perkebunan & 46 & 0,73 \\
\hline Belum bekerja & 3.541 & 55,92 \\
\hline Jumlah & 6.332 & 100 \\
\hline
\end{tabular}

Pemberdayaan masyarakat harus mempertimbangkan kondisi sosial masyarakat desa. Kondisi sosial masyarakat Kelurahan Bukit Datuk akan menentukan strategi dan pendekatan pemberdayaan yang dilakukan. Pemberdayaan yang sesuai dengan keinginan masyarakat akan membuat partisipasi masyarakat menjadi tinggi. Hal ini dikarenakan kondisi sosial merupakan faktor utama yang memengaruhi partisipasi masyarakat dalam pengelolaan hutan (Salampessy, Nugroho, \& Purnomo, 2012).

\section{B. Potensi dan Isu Strategis}

Dalam konteks pemberdayaan masyarakat sekitar area kerja PT. Pertamina RU II Dumai, terdapat beberapa isu strategis yang mengemuka sebagai simpul-simpul untuk dikembangkan dalam program dan kegiatan sesuai dengan tujuan pengelolaan. Isu-isu strategis yang menjadi perhatian merujuk pada kawasan Hutan Patra Seroja serta potensi masyarakat desa-desa area kerja PT. Pertamina RU II Dumai. Beberapa isu strategis tersebut diuraikan sebagai berikut: 


\section{Tingginya keanekaragaman hayati Hutan Patra Seroja}

Hutan Patra Seroja yang berfungsi sebagai kawasan perlindungan keanekaragaman hayati mempunyai arti penting mengingat degradasi hutan yang sangat luar biasa terjadi di Provinsi Riau. Berdasarkan hasil inventarisasi flora dan fauna tahun 2021, tercatat lebih dari 100 jenis pohon ditemukan di Hutan Patra Seroja. Selain itu, untuk jenis flora terdapat 50 jenis burung, 28 jenis herpetofauna, dan 12 jenis mamalia. Di sisi lain, terdapat ancaman dari sektor eksternal di mana masyarakat juga secara ilegal mengambil sumber daya yang ada di dalam hutan seperti satwa liar (burung) dan kayu. Adanya masyarakat yang masuk ke dalam kawasan bisa menjadi ancaman bagi kelestarian hutan (Bakti \& Dodik, 2007).

Pengambilan sumber daya yang dilakukan masyarakat dapat bersifat eksploitatif tergantung dari bagaimana pengetahuan lokal masyarakat dalam pemanfaatan sumber daya hutan. Pengetahuan lokal masyarakat adalah kumpulan pengetahuan dan keyakinan kumulatif yang diturunkan dari generasi ke generasi melalui transmisi budaya, serta hubungan makhluk hidup (termasuk manusia) satu sama lain dan lingkungan (Sinthumule \& Mashau, 2020). Pengetahuan lokal masyarakat memiliki peran yang sangat penting untuk konservasi keanekaragaman hayati dalam pengelolaan kawasan hutan (Susanti \& Zuhud, 2019). Pengetahuan lokal masyarakat memiliki mekanisme sosial dan kultural dalam mengelola ekosistem. Mekanisme tersebut terbentuk dalam kepercayaan lokal, nilai, ritual, adat/budaya dan tabu dalam mengelola sumber daya alam. Dalam pendekatannya, karakter pengetahuan lokal masyarakat merupakan unsur yang harus digali dan diketahui. Karakter pengetahuan lokal masyarakat yang perlu digali untuk mengetahui peran masyarakat dalam pengelolaan hutan Patra Seroja meliputi: a) Taboos; b) Custom and ritual; c) Rules and regulation; dan d) Traditional protected areas, sebagaimana yang disebutkan oleh Boafo et al. (2016).

\section{Potensi peran perempuan dan pemuda dalam pengelolaan keanekaragaman hayati}

Perempuan dan pemuda merupakan kelompok yang menjadi ujung tombak dalam keberhasilan program pemberdayaan. Kelompok perempuan memiliki peran penting dalam pendidikan keluarga. Perempuan juga memiliki peran dalam pengelolaan keanekaragaman hayati, yaitu sebagai pengguna, produsen, komunikator, edukator, maupun konsumen sumber daya hutan (Zunariyah, 2015). Adapun pemuda berpotensi menjadi agen perubahan dan sebagai media mewujudkan ideide baru. Beberapa faktor yang menjadi alasan pemuda untuk ikut berpartisipasi dalam pengelolaan hutan di antaranya adalah adanya pendamping kelompok, pertemuan kelompok, dokumen rencana kerja, bantuan dari berbagai pihak, dan faktor keinginan untuk berpartisipasi (Ilfa, Supratman, \& Sahide, 2021). Pendidikan konservasi dan lingkungan merupakan salah satu kegiatan yang perlu dibangun sejak dini. Kelompok perempuan dan pemuda menjadi golongan yang berpotensi sebagai penggerak. Pendidikan konservasi dapat diterapkan sebagai langkah untuk meningkatkan pemahaman konservasi serta membentuk sikap dan karakter peduli terhadap lingkungan baik bagi perempuan maupun anak-anak (Listiana, 2016).

\section{Ekspansi lahan sawit oleh masyarakat}

Pertumbuhan ekonomi Indonesia sebagian besar bertumpu pada kegiatan ekonomi berbasis lahan and eksploitasi sumber daya alam (Rivai \& Anugrah, 2016). Pemanfaatan lahan dari tahun 90 terjadi secara masif dan berdampak negatif bagi kelestarian 
hutan Indonesia. Salah satu dampak eksploitasi yang banyak terjadi yaitu degradasi hutan karena perluasan perkebunan kelapa sawit. Ekspansi kebun kelapa sawit ke dalam kawasan hutan telah memengaruhi fungsi ekologi, sosial dan ekonomi dari ekosistem hutan (BAPPENAS, 2019). Provinsi Riau merupakan wilayah yang memiliki perkebunan kelapa sawit terluas di Indonesia. Pada tahun 2018, luas perkebunan kelapa sawit di provinsi Riau mencapai 2.706.892 ha dengan produksi 8.496.029 ton atau $19,81 \%$ dari kontribusi Crude Palm Oil (CPO) Nasional (Suryadi, Dharmawan, \& Barus, 2020). Hasil survei lapangan ditemukan adanya perluasan lahan sawit oleh masyarakat Bukit
Datuk di luar lahan yang sudah diberi ijin oleh PT. Pertamina. Masyarakat menjelaskan bahwa tanaman sawit lebih menguntungkan secara ekonomi dan panennya cukup mudah yaitu dengan mendatangkan pihak pengepul untuk memanen. Lahan pertanian yang dikelola juga semakin mengarah menuju pada kawasan Hutan Patra Saroja.

\section{Potensi wisata lokal di Bukit Datuk}

Beberapa unggulan wisata lokal yang dapat dikembangkan di antaranya adalah taman Mina Patra, kolam pancing patra, dan wisata olah raga (lapangan golf) di Kelurahan Bukit Datuk (Gambar 2).
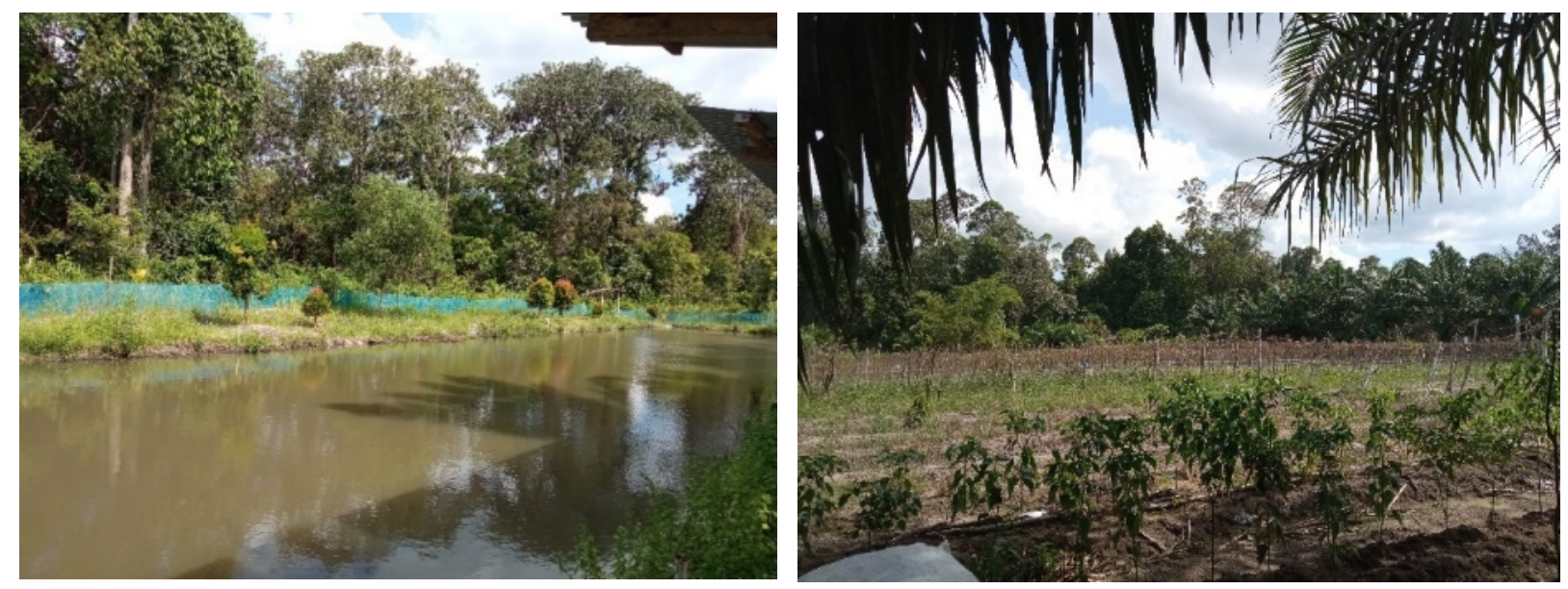

Gambar 2. Lokasi pemancingan (kiri) untuk wisata dan areal pertanian yang merupakan potensi Kelurahan Bukit Datuk

Figure 2. Fishing locations (left) for tourism and agricultural areas of Bukit Datuk Village potential

\section{Permasalahan Sampah}

Permasalahan lingkungan yang mengancam ekosistem hutan di antaranya adalah penumpukan sampah dan tidak adanya lahan penampungan sampah (Gambar 3). Berdasarkan hasil wawancara, masyarakat masih mempunyai budaya membuang sampah secara langsung di batas lahan PT. Pertamina. Dalam hal ini, masyarakat masih mengharapkan bantuan dari PT. Pertamina untuk pengembangan bank sampah serta kegiatan sosialisasi pengelolaan sampah yang efektif dan efisien. 

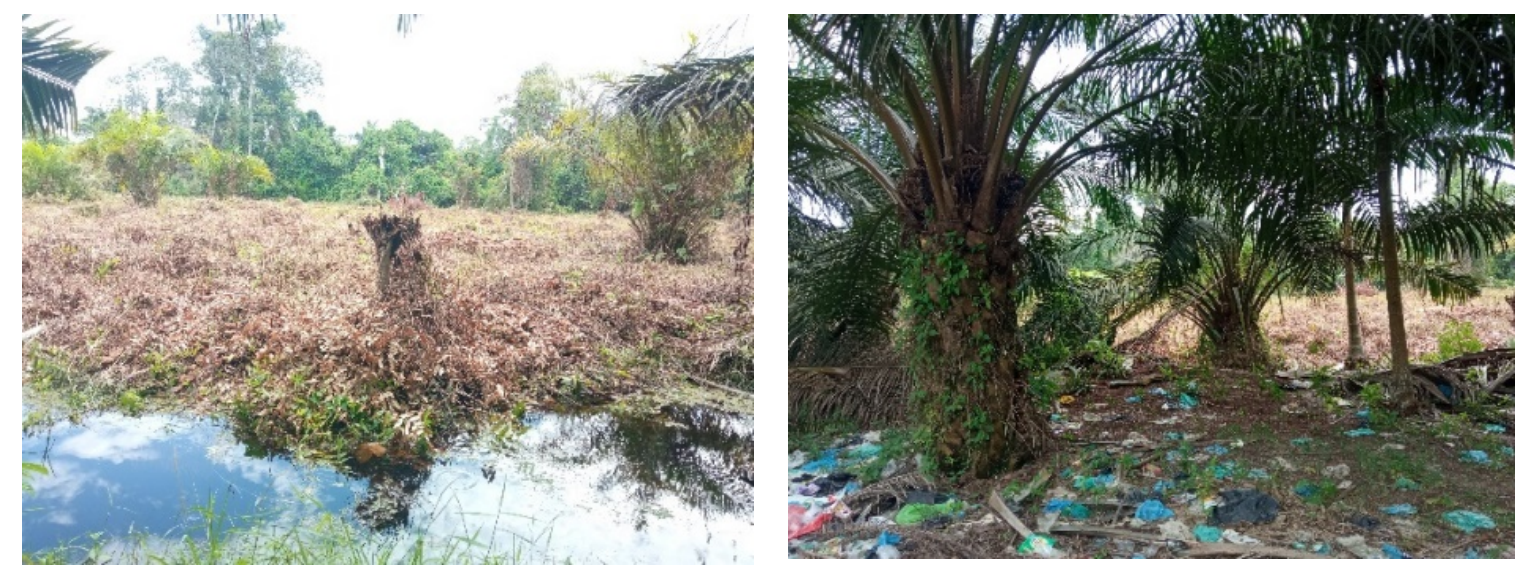

\section{Gambar 3. Problem sampah di Kelurahan Bukit Datuk Figure 3. Waste problem in Bukit Datuk Village}

\section{Potensi Pemberdayaan Masyarakat Kelurahan Bukit Datuk}

Berdasarkan hasil analisis dengan mempertimbangkan isu strategis, diperoleh beberapa program pemberdayaan masyarakat yang sesuai dengan pengelolaan keanekaragaman hayati di Hutan Patra Seroja, di antaranya:

\section{Penguatan kelompok masyarakat mitra dalam menjaga Hutan Patra Seroja.}

Masyarakat mitra merupakan masyarakat yang dibentuk sebagai mitra dalam perlindungan keanekaragaman hayati Hutan Patra Seroja. Kelompok tersebut di antaranya adalah kelompok tani dan beberapa kelompok pemuda yang sudah melakukan kerjasama dengan PT. Pertamina RU II Dumai. Masyarakat merupakan subyek yang dapat memberikan dampak negatif maupun positif dalam keberlanjutan suatu sumber daya. Hutan memiliki sumber daya yang bersifat multi fungsi bagi masyarakat di sekitarnya serta dapat menjadi tempat berinteraksi untuk memenuhi kebutuhan dasar (Ungirwalu et al., 2016). Teori tersebut selaras dengan Theory of Culture Change oleh Steward pada tahun 1955, yang pertama kali mengungkapkan bahwa proses masyarakat mengadaptasi budaya dipengaruhi oleh penyesuaian dasar yang dilakukan manusia dalam menggunakan lingkungannya.

Hutan Patra Seroja merupakan kawasan hutan yang dikelola oleh PT. Pertamina RU II Dumai yang berlokasi di sekitar kawasan penduduk Kelurahan Bukit Datuk. Interaksi antara masyarakat sekitar dan kawasan Hutan Patra Seroja telah terbangun, salah satunya yang dilakukan masyarakat dengan pemanfaatan sumber daya di dalam hutan. Hal ini menunjukkan bahwa terdapat hubungan sinergis yang saling berkaitan antara masyarakat dengan Hutan Patra Serjo. Masyarakat dan hutan dianggap menjadi satu kesatuan utuh yang tidak dapat dipisahkan (Amzu, Sofyan, Prasetyo, \& Kartodihardjo, 2007). Sementara itu, keseimbangan antara pemanfaatan sumber daya Hutan Patra Seroja dalam memenuhi kebutuhan masyarakat dan upaya pengelolaannya perlu dicapai sehingga sumber daya Hutan Patra Seroja tetap terjaga. Salah satu bentuk upaya tersebut adalah melibatkan masyarakat untuk menjaga Hutan Patra Seroja dengan penguatan kelompok masyarakat mitra Hutan Patra Seroja. Penguatan kelompok mitra menjadi salah satu upaya terbaik karena di Kelurahan Bukit Datuk sudah ada beberapa kelompok mitra, di antaranya adalah kelompok tani yang juga ikut menjaga kelestarian Hutan Patra Seroja. 


\section{Pembentukkan kelompok Wanita Tani dalam pengelolaan keanekaragaman hayati}

Kelompok wanita tani dianggap memiliki ketrampilan dan keuletan yang tinggi dibandingkan pria. Selain itu, wanita tani juga memiliki peran dan potensi yang strategis dalam mendukung peningkatan dan perolehan pendapatan rumah tangga pertanian di pedesaan (Ervinawari, Fatmawati, \& Indri, 2015). Jumlah wanita produktif di sekitar Hutan Patra Seroja yang cukup tinggi dapat berperan dalam mendukung pemafaataan sumber daya lokal seperti hasil hutan non kayu secara optimal. Dengan pembentukan kelompok wanita tani, pemanfaatan hasil hutan non kayu yang dapat dikembangkan lebih luas, di antaranya pengolahan daun-daun yang terbengkalai untuk pupuk, kerajinan tangan berupa tas bercorak daun, dan pemanfaatan hasil buah-buahan untuk diolah menjadi makanan. Pemanfaatan potensi lokal ini juga tentu harus tetap dikontrol, sehingga sumber daya hutan dapat lestari.

\section{Pembentukan dan pengembangan kelompok-kelompok masyarakat untuk mengembangkan sumber daya alam di lahan milik/desa untuk tujuan produktif}

Berdasarkan observasi yang telah dilakukan, daerah sekitar Hutan Patra Seroja memiliki jumlah kelompok masyarakat yang relatif sedikit. Kurangnya kelompok masyarakat ini akan semakin memberikan kebebasan individu yang dianggap memicu kecemburuan sosial dan kurangnya antusiasme dalam kegiatan pemanfaatan serta pengembangan sumber daya lahan desa. Oleh sebab itu, pembentukan kelompok menjadi salah satu upaya menjalin kerjasama antar masyarakat dalam peningkatan produktivitas lahan (Sumardjo et al., 2014). Lahan milik desa yang dikelola secara berkelompok ini dapat menghasilkan keadilan dan kesetaraan pemanfaatan lahan (Sitorus, 2016).
Pengembangan kelompok masyarakat merupakan tahap lanjutan setelah terbentuk kelompok masyarakat, yang secara khusus berhubungan dengan aspek pengetahuan umum dan praktek di lapangan. Salah satu kegiatan pengembangan kelompok yang dapat dilakukan adalah pelatihan pengelolaan lahan dengan pola agroforestri (Ruhimat, 2017). Sistem agroforestri merupakan suatu sistem penggunaan lahan dengan mengkombinasikan tanaman pertanian dan tegakan hutan (Mayrowani \& Ashari, 2011). Sistem ini bertujuan untuk mengoptimalkan produktivitas lahan dengan tetap mempertahankan fungsi ekologi serta kualitas jasa lingkungan.

\section{Pemetaan area ekspansi dan penerapan solusi jalan tengah permasalahan lahan sawit}

Beberapa kegiatan yang dapat diterapkan dalam program pemetaan area ekspansi dan penerapan solusi jalan tengah permasalahan lahan sawit, antara lain:

a) Pemetaan ketergantungan ekonomi masyarakat berbasis Kawasan.

Pemetaan ketergantungan ekonomi ini dapat dilakukan dengan observasi fenomena perilaku masyarakat khususnya dalam hal sosial ekonomi masyarakat (Putra \& Dilham, 2017). Berdasarkan hasil pemetaan dapat diketahui seberapa besar ketergantungan ekonomi dalam pemanfaatan lahan untuk tanaman sawit, lokasi lahan sawit mandiri bagi masyarakat, dan luas lahan kepemilikan. Hal ini menjadi dasar perumusan alternatif meningkatkan perekonomian masyarakat dan strategi untuk menghindari adanya ekspansi sawit.

b) Pemetaan lahan yang sudah terekspansi menjadi lahan kelapa sawit

Beberapa masyarakat telah memanfaatkan lahan milik PT. Pertamina RU II Dumai menjadi lahan sawit. Hal ini tentu dapat berdampak pada konflik lahan antara masyarakat dengan PT. 
Pertamina RU II Dumai. Oleh sebab itu, kegiatan pemetaan lahan yang sudah terekspansi menjadi lahan kelapa sawit penting dilakukan untuk menghindari adanya tumpang tindih pemanfaatan Kawasan PT. Pertamina RU II Dumai. Pemetaan lahan juga akan memberikan informasi spasial secara detail baik luas, maupun letak geografis (Maharany, Simbolon, \& Hutagaol, 2019). Hasil pemetaan dapat menjadi bahan pertimbangan dalam perumusan rencana pengelolaan dan monitoring lahan lebih lanjut.

\section{Peningkatan kesadaran masyarakat dan pengembangan sarana prasarana pendukung pengelolaan sampah sekitar Hutan Patra Seroja.}

Permasalahan sampah merupakan salah satu isu strategis yang banyak dijumpai di daerah sekitar PT. Pertamian RU II Dumai. Permasalahan sampah dapat mengganggu kelestarian lingkungan maupun sosial kehidupan masyarakat. Tidak adanya pengelolaan sampah yang baik dapat berdampak terhadap timbulnya berbagai penyakit karena kualitas lingkungan yang buruk. Pengelolaan sampah dapat ditinjau dari lima aspek, yakni: kelembagaan, teknik operasional, regulasi, pembiayaan dan peran serta masyarakat (Suryani, 2014). Langkah awal penyelesaian masalah sampah harus berfokus pada peningkatan kesadaran masyarakat. Hal ini disebabkan mayoritas masyarakat masih membuang sampah tidak pada tempatnya, seperti pada lahan milik Pertamina. Salah satu program implementasi pengelolaan sampah di antaranya pembentukan dan/atau penguatan kelompok pengelola sampah (bank sampah), pemetaan area yang berpotensi sebagai tempat pengolahan sampah, sosialisasi pengelolaan sampah yang ramah lingkungan, dan pendampingan kelompok hingga menuju kemandirian. Peningkatan sarana prasarana penunjang pengelolaan sampah juga merupakan salah satu upaya yang efektif dalam mengatasi permasalah sampah. Apabila dilihat dari kondisi yang ada di desa, sarana prasarana penunjang pengelolaan sampah masih sangat minim. Sebagai contoh tempat sampah jarang ditemukan, dan tempat pembuangan sementara yang belum ada.

\section{KESIMPULAN}

Mayoritas masyarakat Bukit Datuk mempunyai tingkat pendidikan SLTA $(32,32 \%)$ merupakani salah satu potensi pendukung pemberdayaan dalam pengelolaan Hutan Patra Seroja. Di sisi lain mayoritas masyarakat tidak bekerja $(55,92 \%)$ juga dapat menjadi modal dasar pemberdayaan. Isu strategis sosial masyarakat dan kawasan Hutan Patra Seroja yang dapat diangkat untuk pemberdayaan adalah potensi keanekaragaman hayati yang tinggi, peran perempuan dan pemuda dalam pengelolaan keanekaragaman hayati, ekspansi lahan sawit oleh masyarakat, potensi wisata lokal Kelurahan Bukit Datuk, dan permasalahan sampah. Berdasarkan isu strategis tersebut beberapa potensi program pemberdayaan yang dapat dilakukan adalah penguatan kelompok masyarakat mitra dalam menjaga Hutan Patra Seroja, pembentukan dan pengembangan kelompok masyarakat yang memiliki interaksi terhadap kawasan, pengembangan pengelolaan sumber daya alam di lahan milik/desa untuk tujuan produktif, solusi jalan tengah permasalahan lahan sawit melalui agroforestri, peningkatan kesadaran masyarakat serta pengembangan sarana prasarana pendukung pengelolaan sampah sekitar Hutan Patra Seroja.

Hasil penelitian ini diharapkan dapat menjadi dasar implementasi program pemberdayaan yang dilaksanakan oleh PT. Pertamina RU II Dumai. Program pemberdayaan masyarakat di Kelurahan Bukit 
Datuk harus memperhatikan kondisi sosial masyarakat dan kondisi ekologi Hutan Patra Seroja sehingga dapat meminimalkan dampak yang mungkin timbul baik secara ekologi maupun sosial ekonomi. Beberapa hal yang perlu ditingkatkan dari penelitian ini adalah penambahan informasi kondisi sosial demografi masyarakat yang lebih spesifik sehingga potensi pemberdayaan dapat diketahui secara lebih efektif dan efisien.

\section{UCAPAN TERIMA KASIH}

Ucapan terima kasih penulis sampaikan kepada semua pihak yang membantu dalam pengambilan data sampai dengan penyusunan paper ini. Selain itu, penulis juga menucapkan banyak terima kasih kepada Universitas Gadjah Mada selaku afiliasi penulis dan PT. Pertamina (Persero) Refinery Unit II Dumai sebagai mitra dalam kegiatan penelitian pemberdayaan masyarakat Kelurahan Bukit Datuk .

\section{DAFTAR PUSTAKA}

Amzu, E., Sofyan, K., Prasetyo, L.B., \& Kartodiharjo, H. (2007). Sikap Masyarakat dan Konservasi: Suatu Analisis Kedawung (Parkia Timoriana (Dc) Merr.) sebagai Stimulus Tumbuhan Obat Bagi Masyarakat, Kasus di Taman Nasional Meru Betiri. Media Konservasi, 12(1), 22 - 32.

Bakti, A., \& Dodik, R. (2007). Pemanfaatan Sumberdaya Hutan oleh Masyarakat di KPH Banyuwangi Utara. Jurnal Manajemen Hutan Tropika, 13(3), 172-81.

Boafo, Y.A., Saito., Kato, S., Kamiyama, KC., Takeuchi, K., \& Nakahara, M. (2016). The Role of Traditional Ecological Knowledge in Ecosystem Services Management: The Case of Four Rural Communities in Northern Ghana. International Journal of Biodiversity Science, Ecosystem Services and Management, 12(1-2), 24-38. doi: 10.1080/21513732.2015.1124454.

Choiria, I. (2015). Pemberdayan Masyarakat Desa Hutan Melalui Lembaga Masyarakat Desa Hutan (LMDH) sebagai Upaya Meningkatkan Pendapatan Masyarakat (Studi pada LMDH Salam Jati Luhur KPH Nganjuk). Jurnal Administrasi Publik Mahasiswa Universitas Brawijaya, 3(12), 2112-2117.

Ervinawari, V. (2015). Peranan Kelompok Wanita Tani Perdesaan Dalam Menunjang Pendapatan Keluarga (Di Dusun Beringin Desa Sungai Rengas Kecamatan Sungai Kakap, Kabupaten Kubu Raya Provinsi Kalimantan Barat) (Tesis Master). Univeristas Tanjung Pura, Pontianak.

Gerihano, P., Intan, E.K.P., \& Simanjuntak, M.H. (2016). Strategi Pengelolaan Kawasan Hutan Taman Nasional Kerinci Seblat (TNKS) Provinsi Jambi. Jurnal Aplikasi Manajemen, 14(1), 120-125.

Hangi, A., Rizalinda., \& Irwan, L. (2014). Pengetahuan dan Persepsi Masyarakat Terhadap Cagar Alam Raya Pasi Kota Singkawang. Jurnal Protobion, 3(2), 12534.

Heriyanto, N.M., Samsoedin, I., \& Bismark, M. (2019). Keanekaragaman Hayati Flora dan Fauna di Kawasan Hutan Bukit Datuk Dumai Provinsi Riau. Jurnal Sylva Lestari, 7(1), 82-94.

Hesti, S., Thasimmim, S.N., \& Rimayanti, W. (2021). Efektivitas Iklan Traveloka Televisi Konvensional Pada Konsumen Di Era Digital. JURNAL SIMBOLIKA: Research and Learning in Communication Study, 7(1), 57-65. doi /10.31289/simbollika.v7i1.4417.

Ilfa, A.A., Supratman., \& Sahide, M.A.K. 
(2021). Partisipasi Pemuda dalam Pengelolaan Hutan Kemasyarakatan di Desa Kahayya Kabupaten Bulukumba. Jurnal Belantara, 4(1), 26-38.

Listiana, Ida. (2016). Analisis Pelaksanaan Pendidikan Konservasi dengan Perilaku Peduli Lingkungan Pada Mahasiswa Jurusan Geografi Sebagai Kader Konservasi (Skripsi). Universitas Negeri Semarang, Semarang.

Mayrowani., \& Ashari. (2011). Pengembangan Agroforestri untuk Mendukung Ketahanan Pangan dan Pemberdayaan Petani Sekitar Hutan. Forum Penelitian Agro Ekonomi, 29(2), 83-98.

Maharany, R., Simbolon, W., \& Hutagaol, B.B. (2020). Aplikasi GIS Pada Pemetaan Tata Guna Lahan di Afdeling a Kebun Bukit Kausar (Pt. Bukit Kausar Jambi)." BERNAS Agricultural Research Journal, 15(2), 1-8.

Neil, A., Golar., \& Hamzari. (2016). Hutan Bukan Kayu pada Taman Nasional Lore Lindu (Studi Kasus Desa Sidondo I Kecamatan Biromaru dan Desa Pakuli Kecamatan Gumbasa). E-Jurnal Mitra Sains, 4(1), 29-39.

Putra, M.U.M., \& Dilham, A. (2017). Pemetaan Sosial Ekonomi Masyarakat Kecamatan Dumai Timur (Studi Kasus: Kelurahan Bukit Timah). Jurnal Wira Ekonomi Mikroskil, 7(1). 1-8.

Reski, N.A., Yusran., \& Makkarennu. (2017). Rancangan Pemberdayaan Masyarakat pada Pengelolaan Hutan Kemasyarakatan (HKm) Desa Pacekke, Kecamatan Soppeng Riaja, Kabupaten Barru, Sulawesi Selatan. Jurnal Hutan dan Masyarakat, 9(1), 37-43. doi.org/10.24259/jhm.v9i1.2039.
Rivai, R.S., \& Anugrah, I.S. (2016). Konsep dan Implementasi Pembangunan Pertanian Berkelanjutan di Indonesia. Forum Penelitian Agro Ekonomi, 29(1), 13-25.

Ruhimat, I.S. (2017). Peningkatan Kapasitas Kelembagaan Kelompok Tani dalam Pengembangan Usahatani Agroforestry: Studi Kasus di Desa Cukangkawung, Kecamatan Sodonghilir, Kabupaten Tasikmalaya, Provinsi Jawa Barat. Jurnal Penelitian Sosial dan Ekonomi Kehutanan, 14(1), 1-17.

Salampessy, M.L., Nugroho, B., \& Purnomo, H. (2012). Hubungan Karakteristik Responden dengan Partisipasi Masyarakat dalam Kegiatan Pengelolaan Hutan Lindung Gunung Nona Di Kota Ambon Propinsi Maluku. Jurnal Penelitian Sosial dan Ekonomi Kehutanan, 9(3), 149-59. doi.org/10.20886/jpsek.2012.9.3.149-159.

Sinthumule, N.I., \& Mashau, M.L. (2020). Traditional Ecological Knowledge and Practices for Forest Conservation in Thathe Vondo in Limpopo Province, South Africa. Global Ecology and Conservation 22:e00910. doi /10.1016/j.gecco.2020.e00910.

Sitorus, S.R.P. (2016). Perencanaan Penggunaan Lahan. Bogor : IPB Press.

Sugiartono, E., \& Dhamayanthi, W. (2016). Model Pemberdayaan Masyarakat di Sekitar Kawasan Hutan Kabupaten Jember. Seminar Nasional Hasil Penelitian dan Pengabdian Masyarakat 2016. Politeknik Negeri Jember. Jember.https://publikasi.polije.ac.id/index. php/prosiding/article/view/147.

Sugiyono. (2020). Metode Penelitian Kuantitatif Kualitatif dan R\&D. Bandung: Alfabeta. 
Sumardjo., Firmansyah, A., Dharmawan, L., \& Wulandari, Y.P. (2014). Implementasi CSR Melalui Program Pengembangan Masyarakat: Inovasi Pemberdayaan Masyarakat PT. Pertamina EP. Asset 3 Subang Field. Bogor : Care IPB.

Suryadi, S., Dharmawan, A.H., \& Barus, B. (2020). Ekspansi Perkebunan Kelapa Sawit : Persoalan Sosial, Ekonomi dan Lingkungan Hidup (Studi Kasus Kab. Pelalawan, Riau). Jurnal Ilmu Lingkungan, 18(2), 367-74. doi.org/10.14710/jil.18.2.367-374.

Suryani, A.S. (2014). Peran Bank Sampah dalam Efektivitas Pengelolaan Sampah (Studi Kasus Bank Sampah Malang). Jurnal Aspirasi, 5(1), 71-84.

Susanti, R., \& Zuhud, A.M.Z. (2019). Traditional Ecological Knowledge and Biodiversity Conservation: The Medicinal Plants of the Dayak Krayan People in Kayan Mentarang National Park, Indonesia. Biodiversitas, 20(9), 64-79.

Susanto, D., Faida L.R.W., Lubis, F.R.H., \& Hanisaputra, R. (2020). Interaksi Masyarakat Sekitar dengan Kawasan Cagar Alam dan Cagar Alam Laut Pangandaran. Jurnal Belantara, 3(2), 97-
104. doi.org/10.29303/jbl.v3i2.474.

Susanto, D., Nugroho, A., Wiyono, \& Hidayat, R. (2021). Potensi Ekoeduwisata Pendukung Field Research Centre UGM di Kulonprogo. Journal of Forestry Research, 4(1), 1-14.

Ungirwalu, A., Awang, S.A., Maryudi, A., \& Suryanto, P. (2016). Pengelolaan Adaptif Pemanfaatan Buah Hitam (Haplolobus Monticola Blumea) Etnis WandamenPapua (Adaptive Management Utilization of Black Fruit (Haplolobus monticola Blumea) Ethnic Wandamen-Papua). Jurnal Manusia dan Lingkungan, 23(2), 266-275.

Yuwono. (2006). Persepsi dan Partisipasi Masyarakat Terhadap Pembangunan Hutan Rakyat Pola Kemitraan di Kabupaten Musi Rawas Sumatera Selatan. Tesis Program Studi Pengelolaan Sumberdaya Alam dan Lingkungan (Tesis Master). Sekolah Pascasarjana Institut Pertanian Bogor, Bogor.

Zunariyah, S. (2015). Peranan Perempuan dalam Pengelolaan dan Pelestarian Sumber Daya Alam. Prosiding Gender Politik dan Pembangunan Indonesia: Perspektif Multidisiplin. UNS Press. Surakarta. 